\title{
Performance Impact Associated with Ni-Based SOFCs Fueled with Higher Hydrocarbon-Doped Coal Syngas
}

\author{
GREGORY A. HACKETT, KIRK GERDES, YUN CHEN, XUEYAN SONG, \\ and JOHN ZONDLO
}

\begin{abstract}
Energy generation strategies demonstrating high efficiency and fuel flexibility are desirable in the contemporary energy market. When integrated with a gasification process, a solid oxide fuel cell (SOFC) can produce electricity at efficiencies exceeding 50 pct by consuming fuels such as coal, biomass, municipal solid waste, or other opportunity wastes. The synthesis gas derived from such fuel may contain trace species (including arsenic, lead, cadmium, mercury, phosphorus, sulfur, and tars) and low concentration organic species that adversely affect the SOFC performance. This work demonstrates the impact of exposure of the hydrocarbons ethylene, benzene, and naphthalene at various concentrations. The cell performance degradation rate is determined for tests exceeding 500 hours at $1073 \mathrm{~K}\left(800{ }^{\circ} \mathrm{C}\right)$. Cell performance is evaluated during operation with electrochemical impedance spectroscopy, and exposed samples are postoperationally analyzed by scanning electron microscopy/energy dispersive spectroscopy, X-ray photoelectron spectroscopy, and transmission electron microscopy. The short-term performance is modeled to predict performances to the desired 40,000-hours operational lifetime for SOFCs. Possible hydrocarbon interactions with the nickel anode are postulated, and acceptable hydrocarbon exposure limits are discussed.
\end{abstract}

DOI: $10.1007 / \mathrm{s} 40553-015-0044-\mathrm{y}$

(C) ASM International (ASM) and The Minerals, Metals \& Materials Society (TMS) (Outside the USA) 2015

\section{INTRODUCTION}

GASIFICATION is a high-temperature process that produces synthesis gas (syngas- $\mathrm{H}_{2}, \mathrm{H}_{2} \mathrm{O}, \mathrm{CO}, \mathrm{CO}_{2}$, and $\mathrm{CH}_{4}$ ) from coal and biomass feed stocks. The generated syngas is converted into electrical energy by subsequent combustion in a gas turbine ${ }^{[1]}$ or electrochemical reaction in a fuel cell. ${ }^{[2-5]}$ In particular, coupling a solid oxide fuel cell (SOFC) to a gasification process increases the overall cycle efficiency from 39.5 to $45.0 \mathrm{pct}^{[6]}$ or even greater when utilizing anode gas recycling. ${ }^{[7]}$ The fuel cell (FC) emits low levels of $\mathrm{NO}_{X}$ and $\mathrm{SO}_{X}$ and facilitates the separation of $\mathrm{CO}_{2}$ from the exhaust stream for eventual sequestration.

Biomass gasification coupled with carbon sequestration is desirable due to its net negative carbon footprint and the availability of fuel feed stocks. The National

GREGORY A. HACKETT, General Engineer, is with the National Energy Technology Laboratory, 3610 Collins Ferry Road, Morgantown, WV 26507 and also with the Oak Ridge Institute for Science and Education, 1299 Bethel Valley Road, Oak Ridge, TN, 37830. Contact e-mail: Gregory.Hackett@netl.doe.gov KIRK GERDES, General Engineer, is with the National Energy Technology Laboratory. YUN CHEN, Assistant Professor, and XUEYAN SONG, Associate Professor, are with the National Energy Technology Laboratory, and also with the Mechanical \& Aerospace Engineering Department, West Virginia University, Engineering Sciences Building Room G-70, Evansdale Drive, Morgantown, WV 26506. JOHN ZONDLO, Professor, is with the Chemical Engineering Department, West Virginia University, 403 Engineering Sciences Building, Evansdale Drive, Morgantown, WV 26506.

Manuscript submitted November 21, 2013.

Article published online February 21, 2015
Renewable Energy Laboratory estimates the availability of non-methane opportunity biomass to exceed $2.8 \times 10^{11} \mathrm{~kg}$ annually, ${ }^{[8]}$ and the use of such material neutralizes the release of atmospheric carbon species. Gasifiers fueled with opportunity fuel may produce syngas of variable quality, making SOFCs the preferred energy conversion technology due to their ability to reform or electrochemically combust both high- and low-quality fuels. Combined heat and power processes based on SOFCs and biomass gasification have the potential to achieve efficiencies of greater than 85 pct. $^{[9]}$

One essential consideration for integrated gasification and fuel cell (IGFC) systems is the interaction of trace species from the gasification process with the SOFC anode. SOFC anodes typically contain nickel, which is subject to interaction with gas-phase species, even at low concentrations. Syngas delivered from coal, for example, may contain gas-phase trace species covering nearly every element on the periodic table. ${ }^{[10]}$ The trace elemental composition of coal syngas is not readily predictable as it varies with gasifier design, gas cleanup process, coal type, and regional coal source. Limited data exist for SOFC operation on direct syngas, ${ }^{[11,12]}$ and the specific interactions of trace species with the SOFC anode are the subject of continued investigation. ${ }^{[13-23]}$

In order to generate trace element cleanup targets for IGFC applications, data describing deleterious interactions must be collected within a vast parameter spacespanning operating temperature, syngas composition, operating power density, and electrode composition among other parameters. Research has been conducted 
using thermodynamic analysis and predictions to narrow the scope to species that will pass through syngas cleanup processes. ${ }^{[24,25]}$ Potentially interacting elements include mercury $(\mathrm{Hg})$, cadmium $(\mathrm{Cd})$, lead $(\mathrm{Pb})$, selenium (Se), phosphorus (P), sulfur (S), antimony (Sb), chlorine $(\mathrm{Cl})$, arsenic (As), and zinc $(\mathrm{Zn})$. These elements, along with other molecules (such as $\mathrm{HCl}, \mathrm{CH}_{3} \mathrm{Cl}$, and $\mathrm{NH}_{3}$ ), have been studied for their effects on SOFC anodes.

In this research, higher hydrocarbons (HHC) were primarily considered. HHCs are predicted to impact SOFC performance by contributing to accumulation of carbonaceous material in the anode pore structure. The amount and type of tars present in the syngas depend on the gasification conditions. ${ }^{[26]}$ In a study conducted by Singh et al., ${ }^{[27]}$ benzene was used as the primary component when simulating gasification tars; therefore, benzene is considered a representative molecule of aromatics and tars in regard to its effect on SOFC performance. Formation of atomic carbon can take place by either methane cracking (Eq. [1]) or the Boudouard Reaction (Eq. [2]):

$$
\begin{aligned}
& \mathrm{CH}_{4} \rightarrow \mathrm{C}+2 \mathrm{H}_{2}, \\
& 2 \mathrm{CO} \leftrightarrow \mathrm{C}+\mathrm{CO}_{2} .
\end{aligned}
$$

As nickel is an active catalyst for hydrocarbon (HC) cracking reactions, it is postulated that the trace HCs in the fuel will be cracked, depositing nucleating carbon on anode surfaces and ultimately blocking active electrochemical reaction sites. The deposition of elemental surface carbon has been shown using a combination of DFT calculations, kinetic measurements, TGA experiments, and the literature ${ }^{[28]}$ to preferentially adsorb onto five adjacent nickel atoms, stabilizing to form more ordered graphitic deposits.

Tars are found in the gas phase due to the high temperatures involved in gasification. Milne and Evans $^{[29]}$ describe a typical biomass tar composition, which is reproduced in Table I. Singh et al. ${ }^{[30]}$ conducted a thermodynamic analysis of carbon deposition in a SOFC fueled by a biomass gasifier. The group suggested using a hydrocarbon mixture with representative species including benzene (representing one-ring aromatics) and naphthalene (representing two-ring aromatics) being the majority (65 and 20 pct, respectively) of gasified biomass tar. The group concluded that the amount of carbon deposited is sensitive to the steam/carbon ratio, temperature, anode material, and cell operating current density. Deposition decreases with increases in the steam/carbon ratio or with increases in current density. Singh et al. reported a maximum deposition at open circuit voltage (OCV) using syngas fuel doped with 2 pct of a tar mixture, as shown in Figure 1.

This paper reports the effects of exposing a SOFC to HHC-doped syngas fuel. Ethylene, benzene, and naphthalene are used to represent HHC and tars in accordance with the cited literature. Cell performance is probed mainly by electrochemical impedance spectroscopy (EIS). EIS is the primary method for characterizing the electrical behavior of systems in which the
Table I. Typical Composition of Biomass Gasification Tars $^{[29]}$

\begin{tabular}{lc}
\hline Compound & Composition (Wt Pct) \\
\hline Benzene & 37.9 \\
Toluene & 14.3 \\
Other one-ring aromatics & 13.9 \\
Naphthalene & 9.6 \\
Other two-ring aromatics & 7.8 \\
Three-ring aromatics & 3.6 \\
Four-ring aromatics & 0.8 \\
Phenolic compounds & 4.6 \\
Heterocyclic compounds & 6.5 \\
Others & 1.0 \\
\hline
\end{tabular}

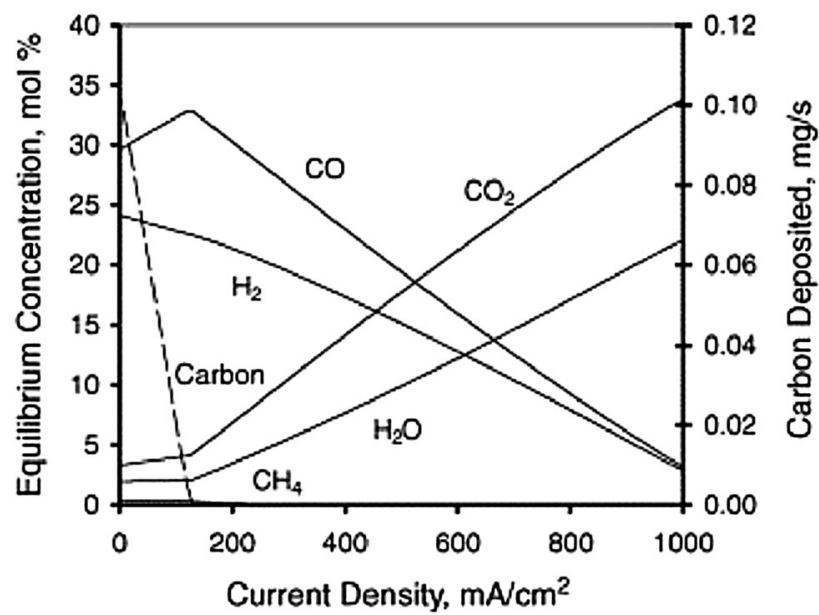

Fig. 1-Equilibrium diagram of main species as a function of current density for a mixture comprising 20 pct $\mathrm{CO}, 15$ pct $\mathrm{H}_{2}, 10$ pct $\mathrm{CO}_{2}, 5$ pct $\mathrm{H}_{2} \mathrm{O}, 2$ pet $\mathrm{CH}_{4}, 48$ pet $\mathrm{N}_{2}$, and tar as 2 pet of the total mixture at $1023 \mathrm{~K}\left(750^{\circ} \mathrm{C}\right) .{ }^{[29]}$

overall system behavior is determined by a number of strongly coupled processes, each of which proceed at a different rate. EIS can provide insights into the different fuel cell operations including oxygen reduction reactions at the cathode, fuel oxidation reactions and transport resistances at the anode, and oxygen ion transport across the electrolyte.

Exposed fuel cell samples are analyzed postoperationally by SEM/EDS, XPS, and TEM for deposits and formation of secondary anode phases. Data are analyzed to predict lifetime performance by applying linear and exponential degradation models. Possible mechanisms of carbon-induced performance degradation are discussed and hydrocarbon exposure limits are postulated.

\section{EXPERIMENTAL}

Anode-supported SOFC button cells with an active area of $2 \mathrm{~cm}^{2}$ were used in each experiment. The button cells were fabricated by Materials and Systems Research, Inc. (MSRI-Salt Lake City, Utah) and feature 


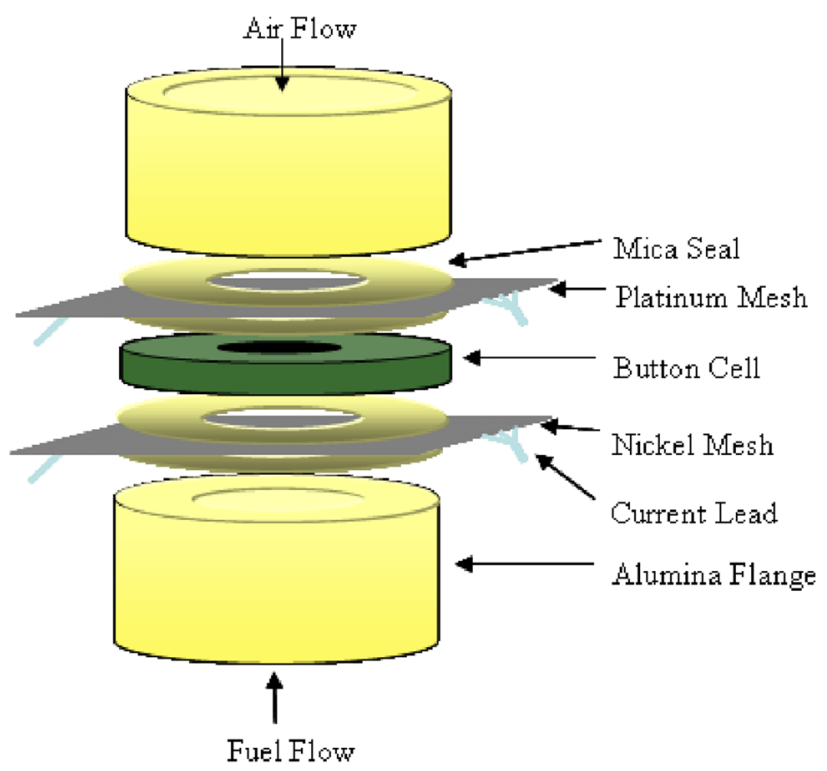

Fig. 2-Schematic of SOFC button cell experimental setup.

a $700-\mu \mathrm{m}$ Ni-8YSZ anode, a $10-$ or $25-\mu \mathrm{m}$ YSZ electrolyte, and a $20-\mu \mathrm{m}$ LSM cathode. The cells also contained a $25-\mu \mathrm{m}$-thick Ni/YSZ anode interlayer featuring a tailored $\mathrm{Ni}$ grain size and a $25-\mu \mathrm{m}$-thick cathode interlayer, which was a composite LSM/YSZ mixture. The bulk layers are utilized for their ability to effectively conduct electrons, while the interlayers (or "active layers") are used for their enhanced mixedconduction capabilities of oxygen ions and electrons. The active layers contain the triple-phase boundary (TPB) where the oxidation/reduction reactions take place and are most sensitive to degradation. A nickel current collecting mesh was attached to the anode using viscous nickel paste, and a platinum mesh was attached to the cathode using platinum paint. Silver current leads and voltage taps were spot welded to the current collecting meshes. The cell was sealed to the test fixture using mica washers and placed between two alumina flanges as shown in Figure 2.

For each experiment, the button cell assembly was mounted in a split tube furnace operated at $1073 \mathrm{~K}$ $\left(800^{\circ} \mathrm{C}\right)$. Digital mass flow controllers (Alicat Scientific-Tucson, Arizona) were used to control the separate fuel constituents and oxidant flow rates. Air was supplied to the cathode as the oxidant at a rate of $1000 \mathrm{sccm}$. The anode (fuel) feed was a syngas mixture consisting of hydrogen (29.1 pct), carbon monoxide (28.6 pct), water (27.1 pct), carbon dioxide (12.0 pct), and nitrogen (3.2 pct) which were blended in the laboratory. The water was added to the dry simulated coal syngas via temperature-controlled humidifier to a total fuel flow rate to $300 \mathrm{sccm}$. The fuel lines were heat traced and insulated to maintain a downstream temperature greater than $373 \mathrm{~K}\left(100{ }^{\circ} \mathrm{C}\right)$ to prevent water condensation. The calculated Nernst potential $\left(E_{\mathrm{N}}\right)$ for the syngas mixture used in this experimentation is $0.965 \mathrm{~V}$. This value is calculated using the equilibrium partial pressure of $\mathrm{O}_{2}$ for the anode gas. The measured open circuit potential for the cells was within $2.0 \pm 1.0$ pct of this value. The losses can be attributed to chemical non-equilibrium or any minor gas leakages through the seals.

Coll et al..$^{[31]}$ determined the relative reactivity of several hydrocarbon molecules to be benzene $>$ toluene $\gg$ anthracene $\gg$ pyrene $>$ naphthalene. To examine HHC with a range of activity plus one possible intermediate reaction product, $\mathrm{HHC}$ molecules benzene, naphthalene, and ethylene were selected for examination. The trace species of interest were added to the fuel by a separate calibrated gas cylinder, a permeation tube, or a diffusion vial. The permeation tube and diffusion vial were supplied by VICI Metronics (Poulsbo, Washington). Trace specie addition via permeation and diffusion was controlled by a precision thermal device (Dynacalibrator 150, VICI Metronics) that controls temperature within $\pm 0.01 \mathrm{~K}$ $\left( \pm 0.01{ }^{\circ} \mathrm{C}\right)$. The operating temperature of the doping device depends on the trace specie vapor pressure, desired concentration, and total fuel flow rate. Cell exposure to the trace species doped syngas was 500 hours.

Once the system reached operating temperature, the anode was reduced from nickel oxide to nickel by delivering mixtures of hydrogen and nitrogen at 300 sccm. Once a steady open circuit voltage (OCV) was observed (within 5 pct of the predicted Nernst potential), the cell was operated galvanostatically at $0.25 \mathrm{~A} \mathrm{~cm}^{-2}$ for 12 hours. Data were observed over this period to ensure steady operation, characterized by a 1-hour noise band of less than $5 \mathrm{mV}$, a 12-hour change in operating voltage in the range of $\pm 10 \mathrm{mV}$, and invariance of output as a function of cathode flow rate.

After stable performance was verified, the cell was exposed to syngas. Water was added to the fuel stream prior to any carbon species being introduced to prevent solid carbon formation. The SOFC was operated galvanostatically at $0.25 \mathrm{~A} \mathrm{~cm}^{-2}$ for $\sim 50$ hours to establish steady baseline power output. The trace specie was then introduced at the desired concentration and the system operated for 500 hours. Data on potential, current, and temperature (cell surface) were collected over the entire period of the experiment.

EIS were collected periodically over the 500-hour test (usually every 100 hours). The HC exposure EIS data were collected using a Solartron 1287 Potentiostat with a Solartron 1260 Frequency Response Analyzer or a Solartron Modulab 2101A. The reported EIS are from measurements taken at open circuit potential. The measured frequency range was between 10,000 and $0.01 \mathrm{~Hz}$. The test was run galvanostatically at potential stimulus amplitude of $10 \mathrm{mV}$.

The exposed fuel cells were post-operationally analyzed by SEM/EDS, XPS, and TEM. All of the TEM examinations were conducted within the anode active layer (within $10 \mu \mathrm{m}$ of the anode and electrolyte interface). TEM samples were prepared by mechanical polishing and ion milling in a liquid nitrogen-cooled holder. Electron diffraction, diffraction contrast, and HR-TEM imaging were performed using a JEM-2100 operated at $200 \mathrm{kV}$. SEM imaging was performed using 
a JEM-7600F operated at $4 \mathrm{kV}$. Chemical analysis was carried out under SEM using EDS.

SOFCs were exposed to 50 and $1000 \mathrm{ppm}$ ethylene, 15 and $150 \mathrm{ppm}$ benzene, and 100 and $500 \mathrm{ppm}$ naphthalene. The concentrations of naphthalene are chosen to be larger than benzene due to the stability of the molecule and to obtain a wider spectrum of carbon loading.

\section{RESULTS}

\section{A. Syngas Benchmark Performance}

To evaluate long-term degradation associated with syngas contaminant exposure, a series of 500-h baseline experiments was conducted. The experimental setup was identical to that previously described except no hydrocarbon contaminant was doped into the syngas fuel. As shown in Figure 3(a), a linear fit of the potential data shows a degradation of $0.6 \mathrm{pct} / 1000$ hours. The EIS (Figure 3(b)) shows an increase in polarization resistance from 0.23 to $0.26 \Omega \mathrm{cm}^{2}$, an indication of some increase in the electrochemical resistance to the overall reaction. The series resistance also increases from 0.46 to $0.73 \Omega \mathrm{cm}^{2}$, indicating a degradation of the contact materials in the setup. An analysis of the Bode plot (Figure 3(b) inset) reveals some small degradation in the 10 to $150 \mathrm{~Hz}$ range, which could correspond to surface oxygen exchange at the cathode and also in the 0.1 to $1 \mathrm{~Hz}$ range that could correspond to gas diffusion resistance at the anode. ${ }^{[32]}$ A second baseline exposure test resulted in a linear degradation of $0.8 \mathrm{pct} /$ 1000 hours, which confirmed that the result is acceptably reproducible for these studies.

Operation on clean syngas neither yields any remarkable microstructural changes nor generates any unexpected features within the anode or electrolyte. The formation of a $\mathrm{NiO}$ layer at the boundary of $\mathrm{Ni}$ and YSZ particles was noted after TEM analysis, consistent with previous reports in the literature. ${ }^{[33]}$ Also, the

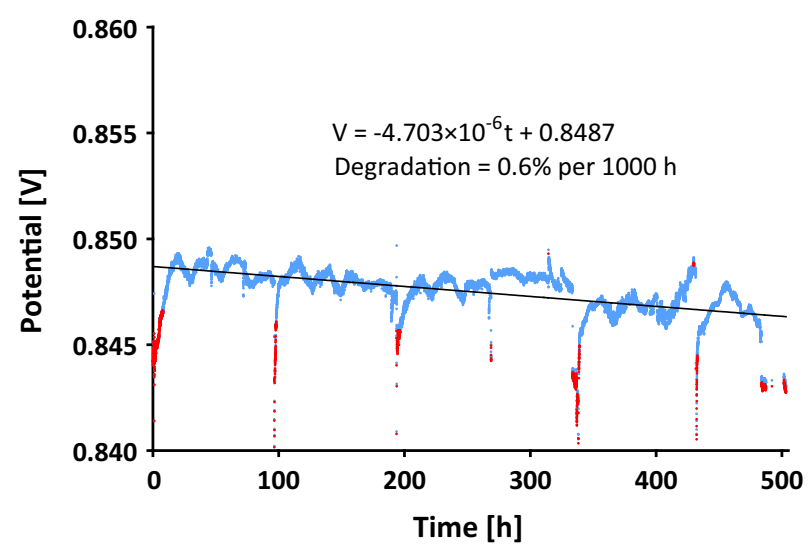

(a) electrolyte structure evolved from purely cubic YSZ $(c$-YSZ) to a mixture of tetragonal YSZ ( $t$-YSZ) and $c$-YSZ as noted in the literature. ${ }^{[34]}$ Because these features are present in the baseline samples, they are postulated to contribute to the baseline degradation and are not caused by hydrocarbon interaction. Other than the noted crystallographic features, the anode microstructure appeared unchanged, and no instances of grain agglomeration, cracking, dusting, or other mechanical flaws were noted.

\section{B. Hydrocarbon Exposure}

Six fresh SOFC button cells were tested under identical conditions as described above, except each cell was exposed to syngas doped with either benzene (15 and $150 \mathrm{ppm})$, naphthalene (100 and $500 \mathrm{ppm})$, or ethylene (50 and $1000 \mathrm{ppm})$. Figures 4 through 6 show the temporal potential and polarization resistance $\left(R_{\mathrm{P}}\right)$ curves for benzene (Figure 4), naphthalene (Figure 5), and ethylene (Figure 6). It is clear that intensified degradation is observed for the cases of exposure to $500 \mathrm{ppm}$ naphthalene and $1000 \mathrm{ppm}$ ethylene. The normalized EIS in Figures 4 through 6 reflect the same result. For benzene, the $R_{\mathrm{P}}$ is between 0.3 and $0.4 \Omega \mathrm{cm}^{2}$ (requires extrapolation to extend data to intersect the imaginary axis) for both concentrations, but there is no discernible temporal pattern for the $150 \mathrm{ppm}$ benzene case (Figure 4(d)). The Bode plots for benzene (Figures 4(b) and (d) insets) show very little resistance increase in any of the frequency regions of interest. This is in agreement with the observation that the potential degradation is not much higher than the baseline degradation. The result is similar for ethylene $\left(0.3 \Omega \mathrm{cm}^{2}\right)$, but the low $R_{\mathrm{P}}$ was not expected for the $1000 \mathrm{ppm}$ case. The Bode plots (Figures 6(b) and (d) insets) also reflect the lack of increase in $R_{\mathrm{P}}$ due to the insubstantial increase in resistance at the frequency ranges of interest. Naphthalene, however, shows a clear increase in $R_{\mathrm{P}}$ over time for both concentrations and a

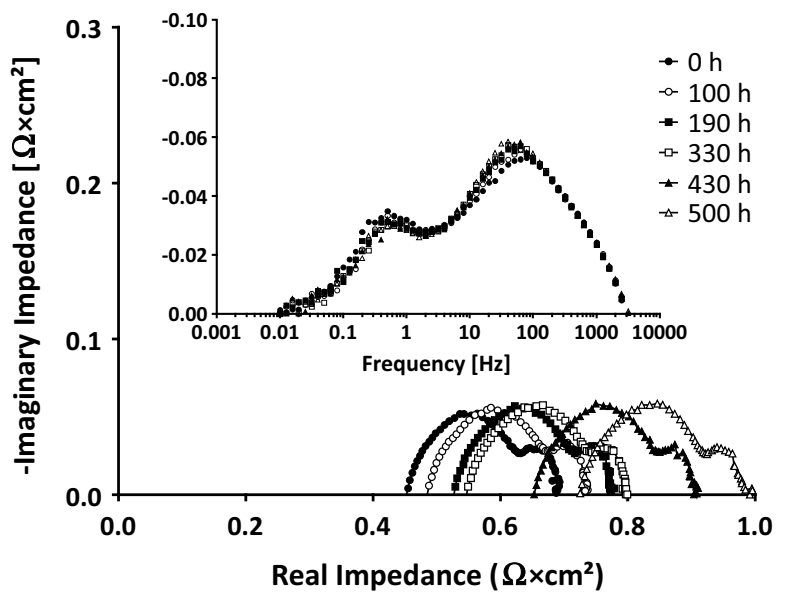

(b)

Fig. 3- Syngas baseline results depicted by (a) Fitted temporal potential plot and $(b)$ total resistance temporal plots obtained from EIS. Cell was operated at $1073 \mathrm{~K}\left(800^{\circ} \mathrm{C}\right)$ and $0.25 \mathrm{~A} \mathrm{~cm}^{-2}$. 


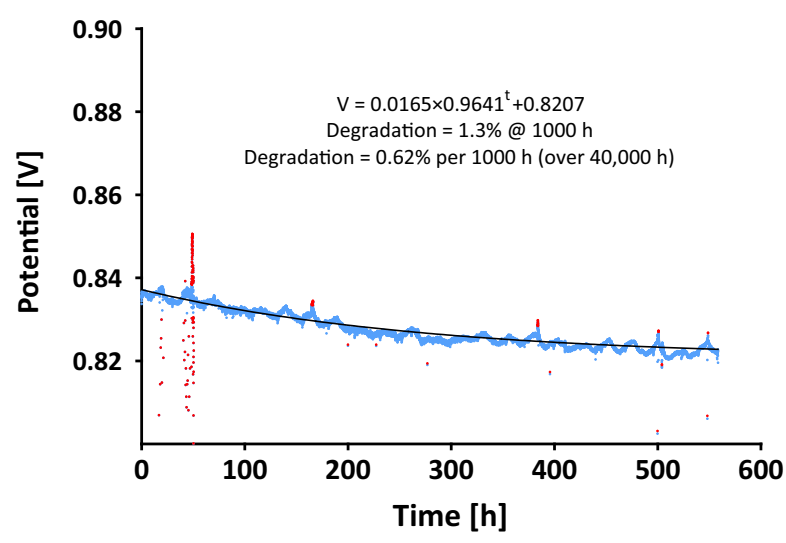

(a)

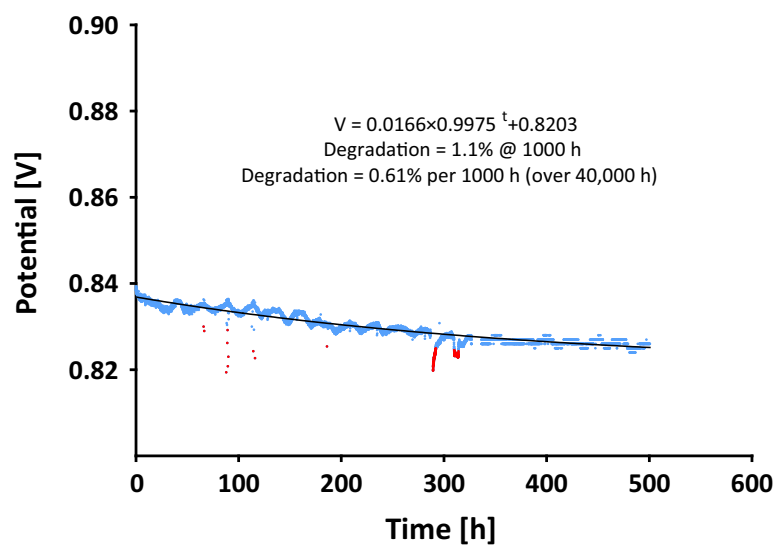

(c)

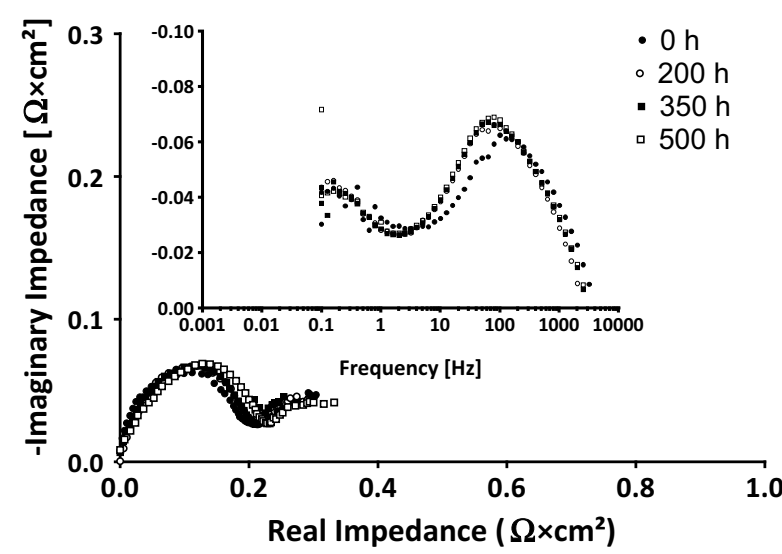

(b)

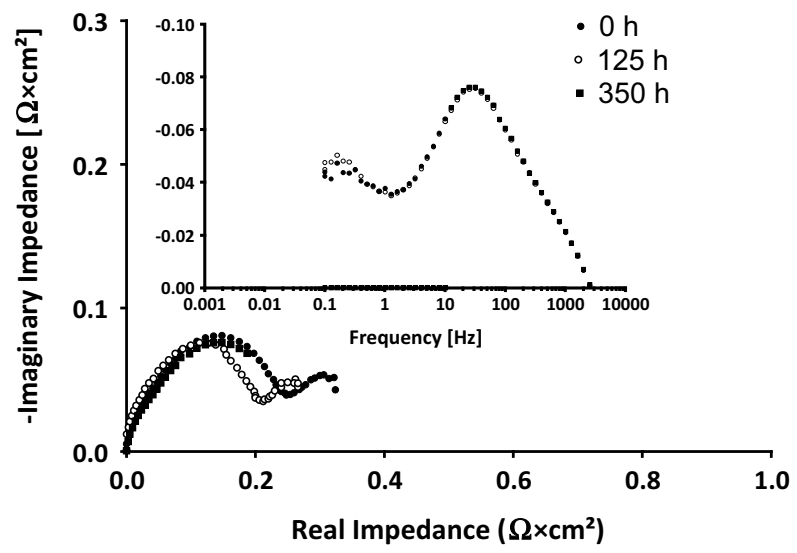

(d)

Fig. 4-Benzene exposure results depicted by (a) $15 \mathrm{ppm}$ fitted temporal potential plot, (b) $15 \mathrm{ppm}$ normalized temporal polarization resistance plots obtained from EIS, (c) $150 \mathrm{ppm}$ potential plot, and (d) $150 \mathrm{ppm}$ polarization resistance plots. Cell was operated at $1073 \mathrm{~K}\left(800{ }^{\circ} \mathrm{C}\right)$ and $0.25 \mathrm{~A} \mathrm{~cm}^{-2}$.

significantly greater absolute magnitude than for benzene or ethylene. In the $100 \mathrm{ppm}$ case, the $R_{\mathrm{P}}$ increases from 0.7 to $0.9 \Omega \mathrm{cm}^{2}$, while in the $500 \mathrm{ppm}$ case, the increase is from 0.4 to $0.8 \Omega \mathrm{cm}^{2}$. Of particular note in the $500 \mathrm{ppm}$ naphthalene case, polarization resistance from $t=0$ hour to $t=500$ hours doubles, which is a significantly greater increase than observed in any other case. These results are also clearly reflected in the Bode plots (Figures 5(b) and (d) insets). A very large increase is seen in the $>150 \mathrm{~Hz}$ range, which is indicative of resistances in the charge-transfer reaction and ionic transport in the anode active layer (near the TPB). ${ }^{[32]}$ This is also visible to a larger extent in the $500 \mathrm{ppm}$ naphthalene EIS plots.

Degradation rates for each exposure series were determined by applying both a linear model and a one-phase decay model in the form of Eq. [3], where $V$ is the potential at time $t, P$ is a plateau value at infinite $t, k$ is the rate constant, and $V_{0}$ is the initial potential:

$$
V=\left(V_{0}-P\right) e^{-k t}+P \text {. }
$$

In all cases, the one-phase decay model produces the best fit $\left(R^{2} \rightarrow 1\right)$ and is used to compare degradation for all specimens tested. Degradation is determined from the one-phase decay model both for the first 1000 hours and as an average rate over 40,000 hours. To predict an average decay rate for 40,000 hours, the one-phase decay rate is assumed until the instantaneous rate is equal to the baseline degradation of $0.6 \mathrm{pct} /$ 1000 hours, which is then adopted as the linear decay rate for the remainder of the 40,000-h period. The summarized results for all specimens are shown in Table II, for both the linear and one-phase decay models.

\section{Post-trial Analysis}

Operational data indicated clear degradation in performance following HHC exposure. Therefore, each cell was post-operationally analyzed by SEM/EDS and XPS in an effort to detect changes in the cell surface, bulk, and microstructure that may indicate the physical source of degradation. Some cells were also analyzed by HR-TEM to better understand the evolution of anode and electrolyte crystal structures. An SEM image of the cross section for each contaminant exposed cell is given in Figure 7. Qualitatively minor changes in the microstructure are observed for the benzene sample (Figure 7(b)) 


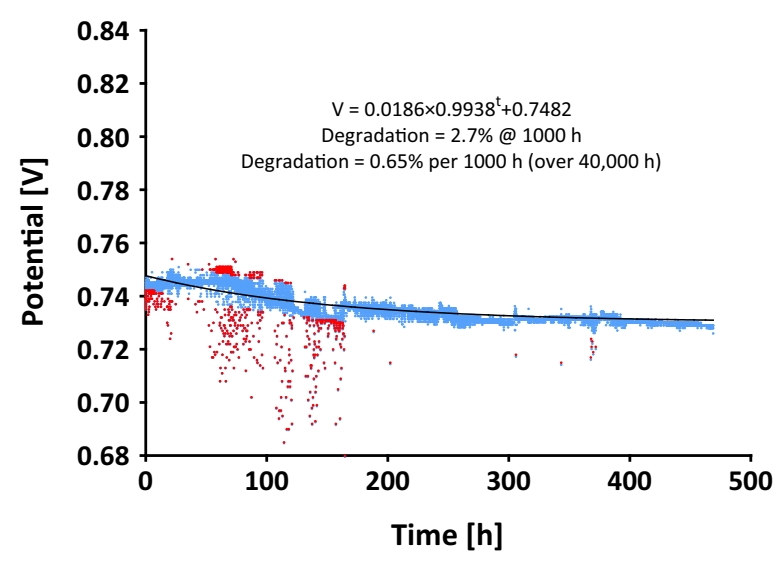

(a)

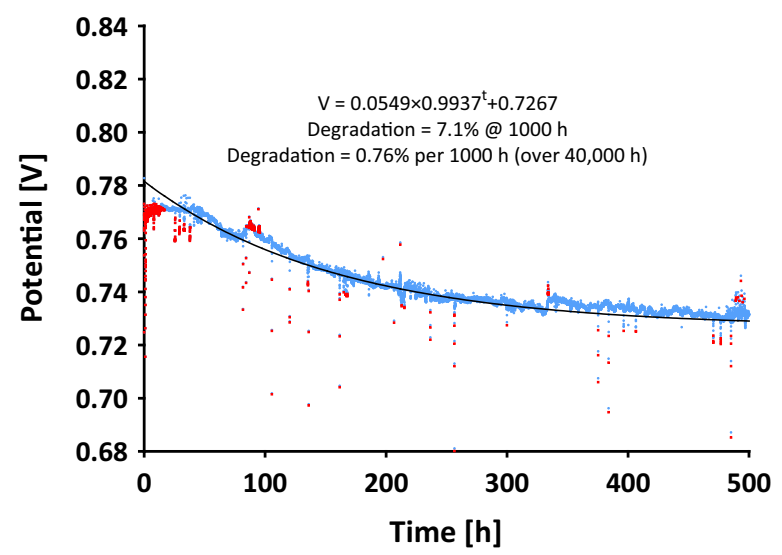

(c)

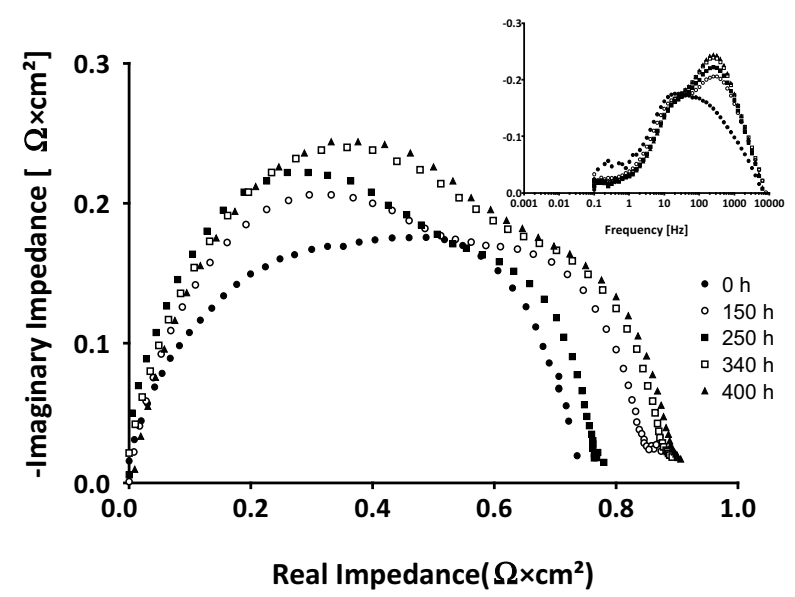

(b)

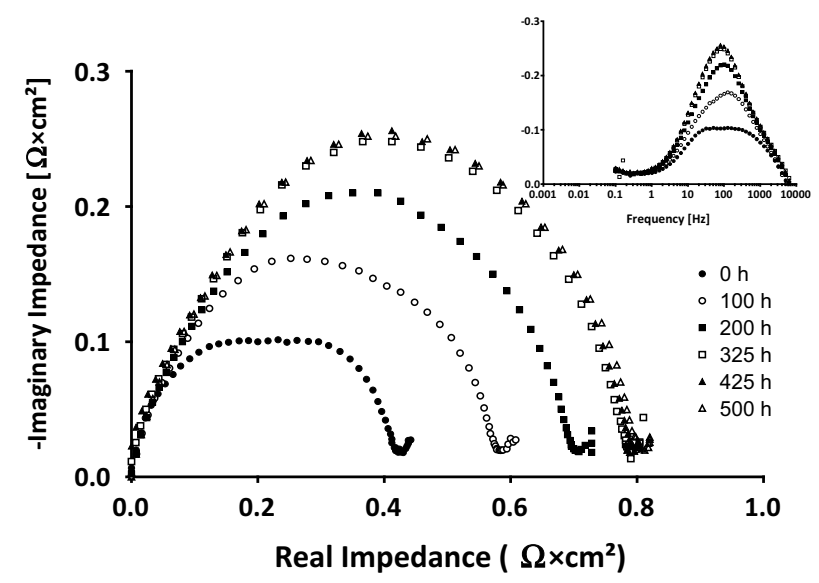

(d)

Fig. 5-Naphthalene exposure results depicted by $(a) 100$ ppm fitted temporal potential plot, (b) 100 ppm normalized temporal polarization resistance plots obtained from EIS, (c) $500 \mathrm{ppm}$ potential plot, and (d) 500 ppm polarization resistance plots. Cell was operated at $1073 \mathrm{~K}$ $\left(800{ }^{\circ} \mathrm{C}\right)$ and $0.25 \mathrm{~A} \mathrm{~cm}^{-2}$.

compared to the baseline sample (Figure 7(a)), though the image of the ethylene sample (Figure 7(d)) shows slightly greater concentration of microstructural flaws (including large pore inclusions) in the anode structure. In contrast, substantial microstructural damage is evident in the naphthalene sample (Figure 7(c)) and appears as pitting corrosion in the anode bulk support structure. Pitting is a form of extremely localized corrosion that leads to the creation of small holes in a metal structure. The corrosion penetrates the mass of the metal, with limited diffusion of ions. Similar pitting was also noted on the $100 \mathrm{ppm}$ naphthalene image. In order to determine the reproducibility of this pitting corrosion, a repeat exposure to $500 \mathrm{ppm}$ naphthalene was conducted on a fresh cell. Pitting was not detected on the repeat exposure sample as shown in Figure 8, although similar performance degradation was observed as in the original test. An increase in pore size and distribution is noted for this sample, but the characteristic spherical corrosion pits are absent.

A TEM image of the area near the active triple-phase boundary shows columnar $\mathrm{NiO}$ formation on the surface at a pore, as shown in Figure 9(a). The columnar grains are about $50 \mathrm{~nm}$ in size and cover the anode backbone surface, including both the Ni and YSZ. This is also found in the repeat exposure sample and to a larger degree (about $100 \mathrm{~nm}$ ) as shown in Figure 9(b).

A notable increase in nickel grain size is evident in Figure 10 for the naphthalene exposed sample when compared to the benzene exposed sample. This feature could not be verified in the repeated test. Nickel oxide and grain agglomeration are primarily observed in the nickel within the current collecting regions of the anode and are not as pronounced in the anode active layer. XPS did not detect any surface carbon above baseline contamination levels for any of the samples.

\section{DISCUSSION}

Evidence collected during the examination of degradation effects on temporal cell overpotential, polarization resistance, and crystallographic and microstructural stability were presented in the results section of this work. Notably absent from all analyses was detection of substantial residual carbon material (deposits or 


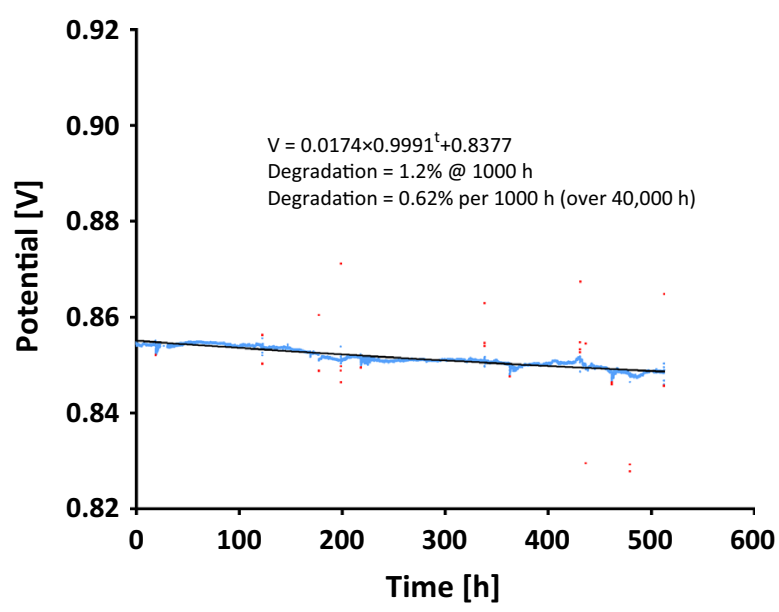

(a)

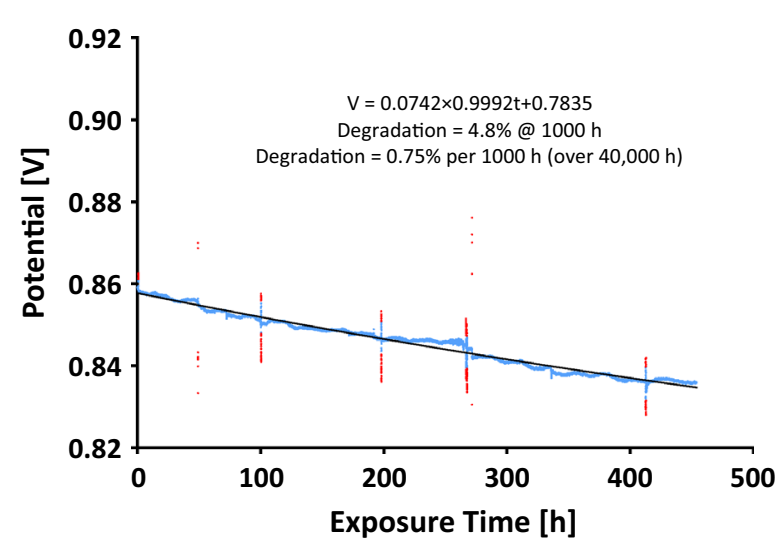

(c)

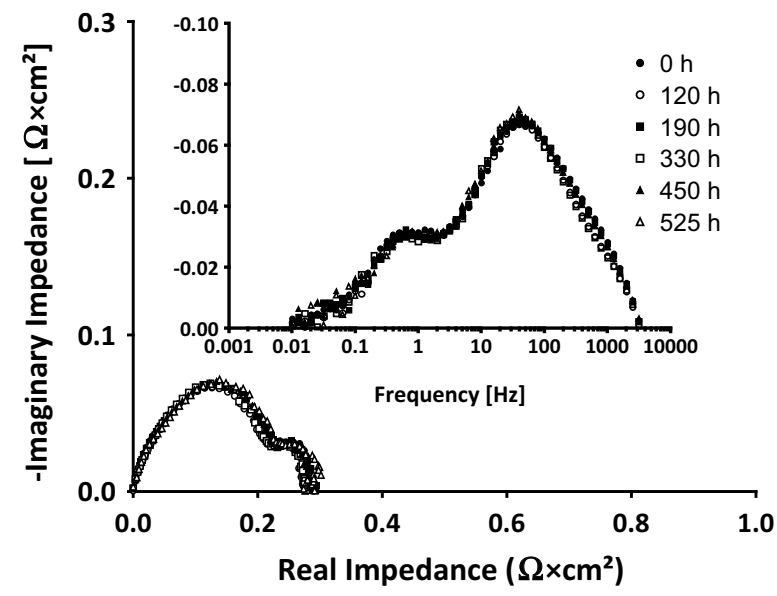

(b)

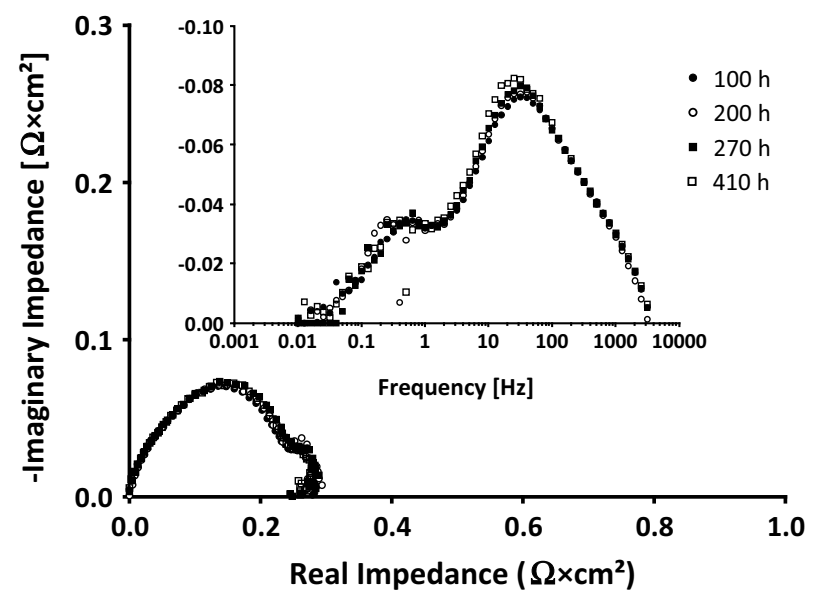

(d)

Fig. 6-Ethylene exposure results depicted by (a) $50 \mathrm{ppm}$ fitted temporal potential plot, (b) $50 \mathrm{ppm}$ normalized temporal polarization resistance plots obtained from EIS, (c) $1000 \mathrm{ppm}$ potential plot, and (d) $1000 \mathrm{ppm}$ polarization resistance plots. Cell was operated at $1073 \mathrm{~K}\left(800{ }^{\circ} \mathrm{C}\right)$ and $0.25 \mathrm{~A} \mathrm{~cm}^{-2}$.

Table II. Summary of Results Obtained From Curve Fitting the Temporal Potential Trends

\begin{tabular}{|c|c|c|c|c|c|c|}
\hline Test & Contaminant & Conc. (Ppm) & Carbon Loading (Ppm) & $R^{2}$ & Deg@1000 Hours (Pct) & Deg@40,000h (Pct) \\
\hline \multicolumn{7}{|c|}{ Linear model: $V=$ Slope $\times$ Time $+V_{0}$} \\
\hline 1 & benzene & 15 & 90 & 0.8817 & 2.88 & fail \\
\hline 2 & benzene & 150 & 900 & 0.9047 & 2.69 & fail \\
\hline 3 & naphthalene & 100 & 1000 & 0.7227 & 4.39 & fail \\
\hline 4 & naphthalene & 500 & 5000 & 0.8599 & 11.47 & fail \\
\hline 5 & ethylene & 50 & 100 & 0.8929 & 1.46 & 58.4 \\
\hline 6 & ethylene & 1000 & 2000 & 0.9806 & 5.90 & fail \\
\hline \multicolumn{7}{|c|}{ Decay model: $V=\left(V_{0}-\right.$ plateau $) e^{-\mathrm{kt}}+$ plateau } \\
\hline 1 & benzene & 15 & 90 & 0.9469 & 1.27 & 24.8 \\
\hline 2 & benzene & 150 & 900 & 0.9315 & 1.10 & 24.4 \\
\hline 3 & naphthalene & 100 & 1000 & 0.8603 & 2.68 & 26.0 \\
\hline 4 & naphthalene & 500 & 5000 & 0.9832 & 7.12 & 30.4 \\
\hline 5 & ethylene & 50 & 100 & 0.8965 & 1.21 & 24.8 \\
\hline 6 & ethylene & 1000 & 2000 & 0.9829 & 4.83 & 30.0 \\
\hline
\end{tabular}

inclusions) appearing as either amorphous or crystalline bulk agglomerations or as surface adsorbed species. The absence of detectable carbon in spite of measureable degradation is consistent with a report by Koh et al. ${ }^{[35]}$ in which a SOFC was exposed to a dry methane fuel stream and operated at $200 \mathrm{~mA} \mathrm{~cm}^{-2}$. In that report, the cell voltage drops steadily over a 500-hour test, yet examination revealed coke only on the feed tube and no 

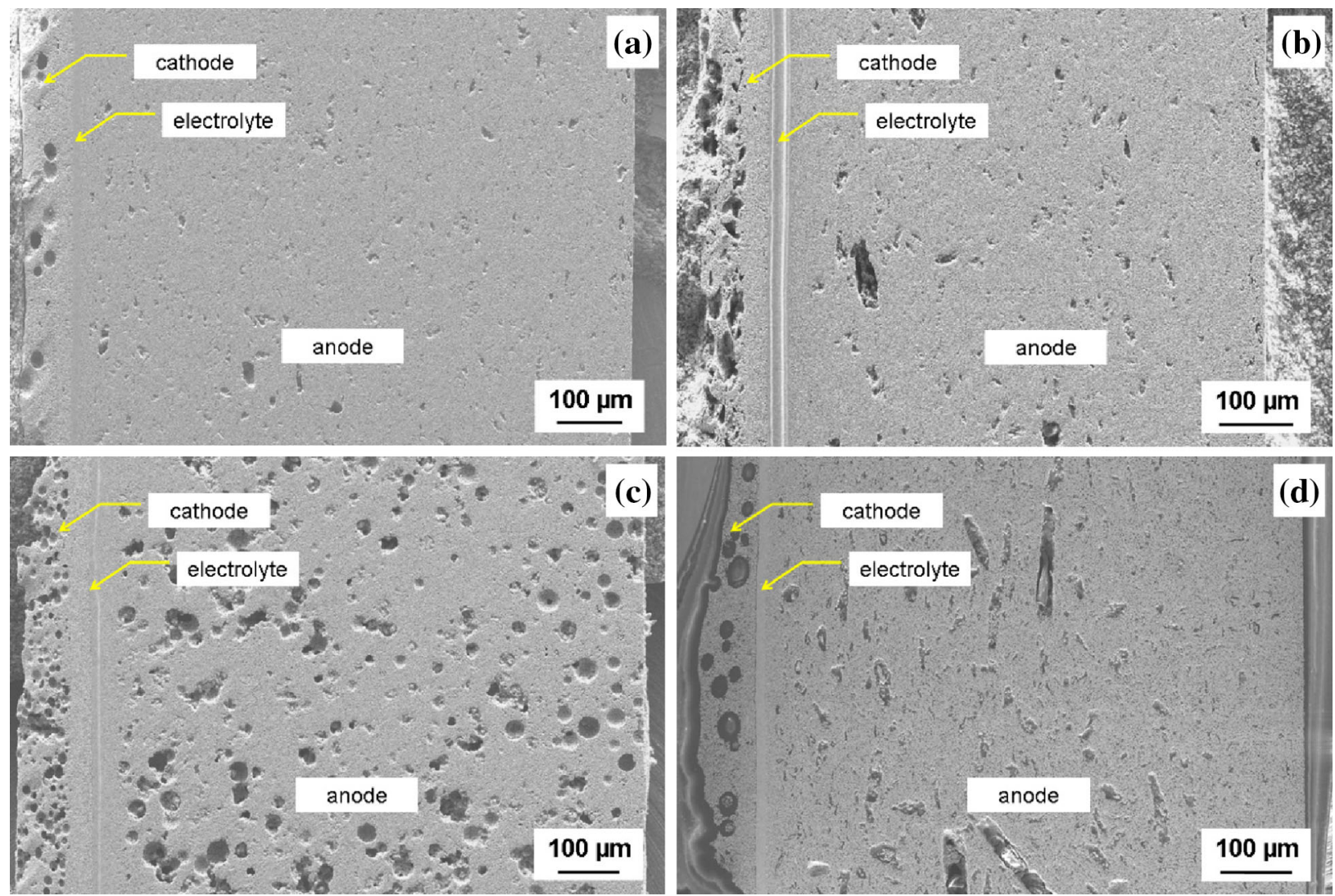

Fig. 7 - Cross-sectional SEM image of (a) Baseline syngas sample, (b) $150 \mathrm{ppm}$ benzene exposed sample, (c) 500 ppm naphthalene exposed sample, and $(d) 1000$ ppm ethylene exposed sample.

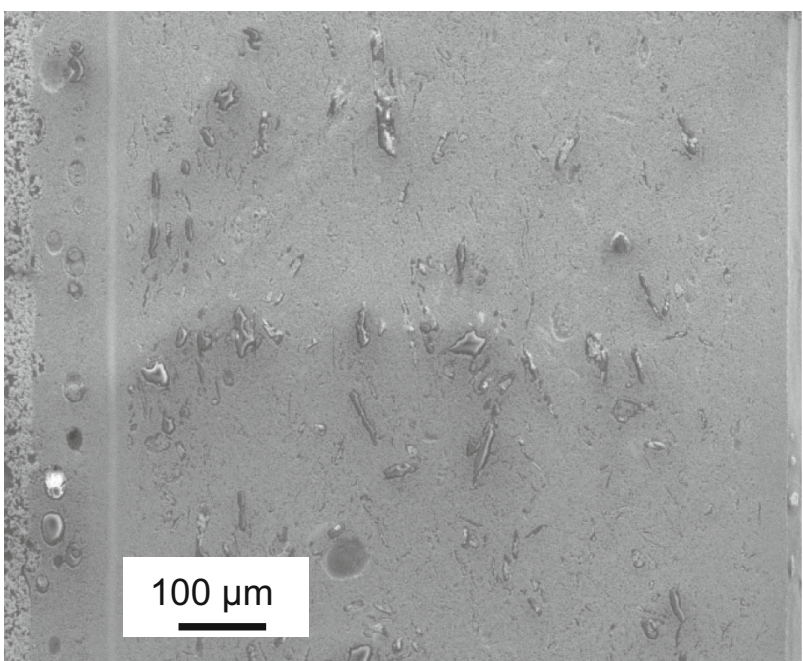

Fig. 8- Cross section of repeated $500 \mathrm{ppm}$ naphthalene exposure. Despite similar degradation, no pitting was detected.

carbon on the anode surface. For lack of evidence of any degradation related to deposition of bulk carbon, attention is focused primarily on the microstructural evolution and EIS to determine the source of the performance degradation.

Evidence of pitting or corrosion-like attack of the nickel particles is observed in certain samples, but this result was not consistently produced in all specimens, including those obtained from repeat tests. According to the literature, metal dusting is a feasible mode of microstructure corruption of nickel metal, and many examples of thermochemical attack have been reported. ${ }^{[36-40]}$ In a typical thermochemical metal-dusting mechanism, Ni corrodes by a combination of atom migration through surface carbon deposits as well as carbon intrusion and precipitation in the bulk metal. The process leaves fine nickel and carbon grains that are unconnected in the percolation network. ${ }^{[37]}$ During the cool-down process used here, the $\mathrm{Ni}$ and carbon particles were exposed to some partial pressure of oxygen, possibly resulting in removal of carbon and generation of the $\mathrm{NiO}$ structures shown in Figure 9. A repeat test, cooled under reducing conditions (1.5 pct $\mathrm{H}_{2}$, balance $\mathrm{N}_{2}$ ), also showed no residual carbon deposits. Similar results were also obtained in a purely thermochemical test by $\mathrm{He}$ et al ${ }^{[41]}$ after exposure of $\mathrm{Ni}$ / YSZ pellets to humidified methane for 4 hours. Significant carbon formations developed including carbon nanotubes at temperatures up to $973 \mathrm{~K}\left(700^{\circ} \mathrm{C}\right)$. At $1073 \mathrm{~K}\left(800{ }^{\circ} \mathrm{C}\right)$, all of the carbon appeared to have dissolved into the nickel particles, and SEM results showed that the nickel particles became sponge-like.

Increased nickel mobility is also observed in specimens exposed to the highest carbon activity. Significant increases are observed in the nickel grain size of the initial naphthalene exposed sample (Figure 10), which is 


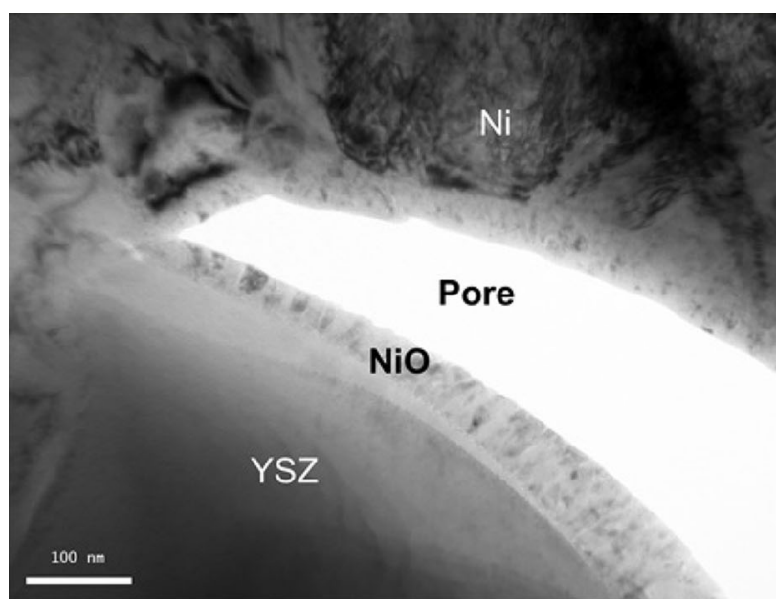

(a)

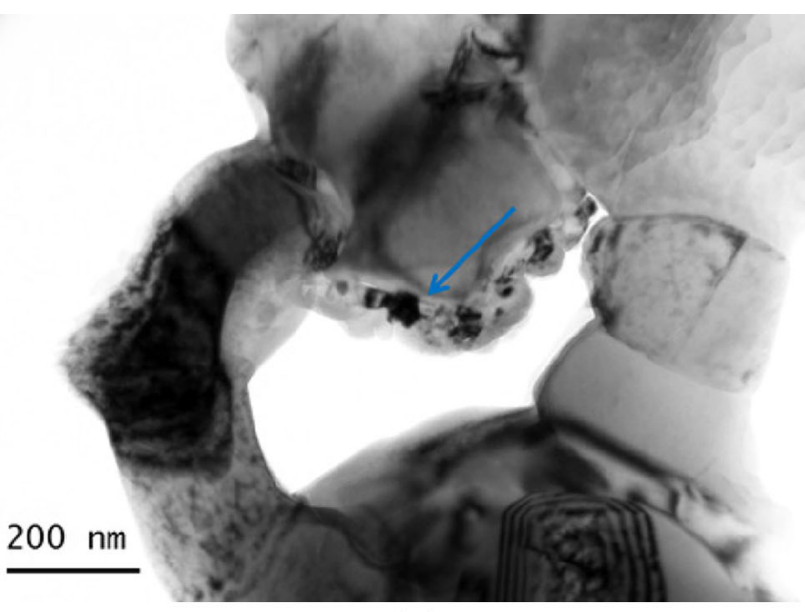

(b)

Fig. 9-TEM image of $500 \mathrm{ppm}$ naphthalene sample showing evidence of columnar $\mathrm{NiO}$ formation for $(a)$ original 500 -h test and $(b)$ repeated exposure test.

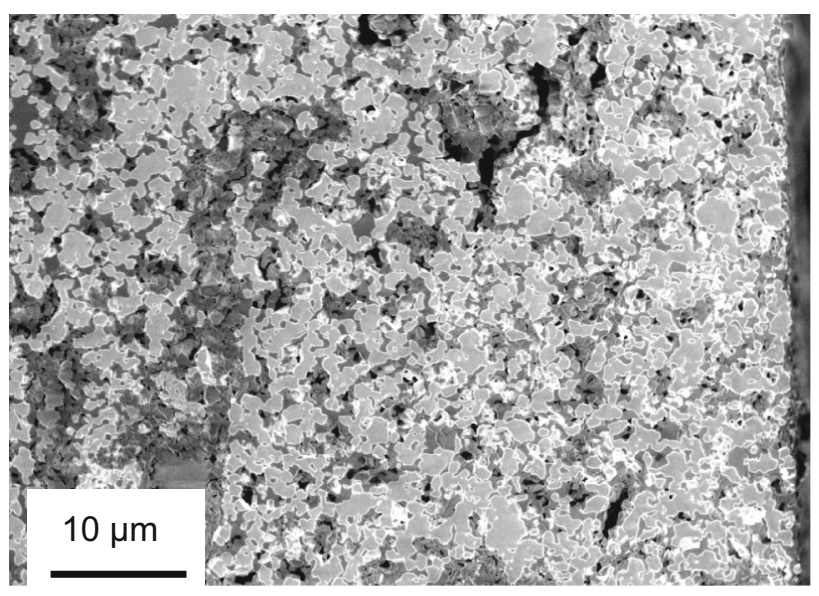

(a)

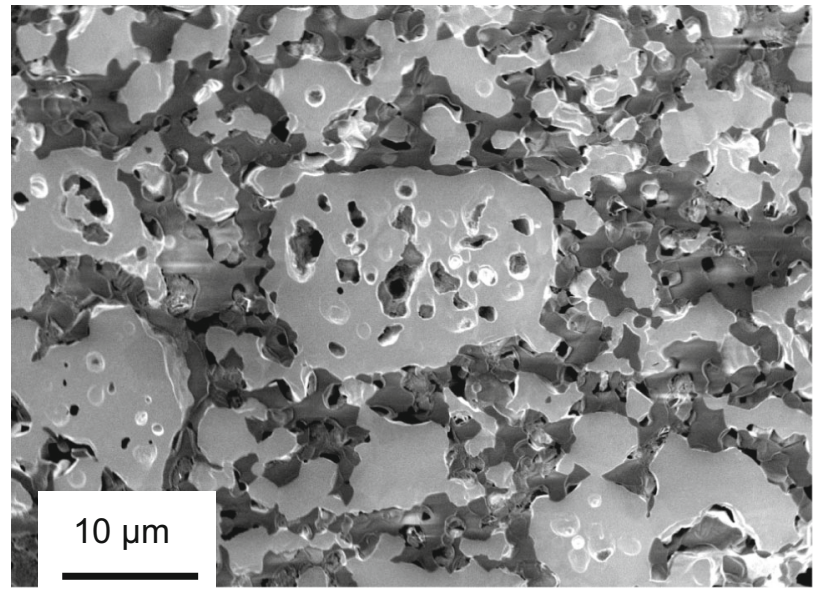

(b)

Fig. 10-Same magnification comparison of nickel grain size as taken from (a) $150 \mathrm{ppm}$ benzene sample and (b) 100 ppm naphthalene sample.

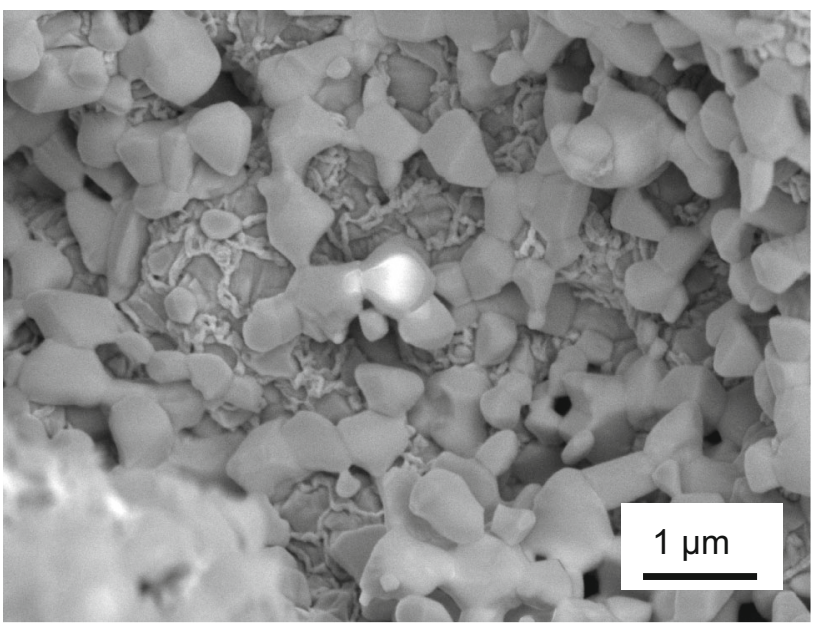

Fig. 11-Example of $\mathrm{NiO}$ ridge structure formations found on nickel particles (no formations on YSZ particles) in the sample exposed to 1000 ppm ethylene. suspected of affecting the percolation network and increasing the resistance to activation/diffusion, as evidenced by the $R_{\mathrm{P}}$ increase over time. This was not detected in the repeat naphthalene exposure sample. Nickel mobility may also explain the performance degradation in the $1000 \mathrm{ppm}$ ethylene sample. This sample demonstrated the second greatest rate of performance degradation, but instead of obvious pitting corrosion, Figure 11 shows the formation of ridgeshaped features on the exposed nickel surfaces. As shown by the EDS analysis summarized in Table III, these formations are composed of $\mathrm{NiO}$ which are not present in the baseline sample, and no such features are observed on the YSZ surface. Due to the large electron beam spot size under SEM and relatively small $\mathrm{NiO}$ ridge structure features, spectrum signals representing only nickel particles were not possible, meaning zirconium is always present in point shot data. However, zirconium should be in the form $\mathrm{ZrO}_{2}$, implying that oxygen in the formation should be close to two times the 
zirconium atomic concentration. For example, the EDS data show a total of 55-at. pct oxygen is present and only $\sim 6$-at. pct zirconium is present. It is therefore postulated that the additional oxygen comes from the formation of $\mathrm{NiO}$.

From the EIS measurements taken on cells that showed a high-performance degradation (as shown in Figures 3 through 6), the increase in resistance in the $>150 \mathrm{~Hz}$ range is postulated to arise from resistances in the charge-transfer reaction and ionic transport in the anode active layer (near the TPB). ${ }^{[32]}$ The data seem to contradict the proposition of physical blocking of fuel feed channels, which would manifest as impedance features in the 0.1 to $1 \mathrm{~Hz}$ range. It is feasible for carbon to diffuse into the nickel structure and form a solid

Table III. Representative EDS Point Analysis Data Taken from Sample Exposed to 1000 ppm Ethylene (See Fig. 11)

\begin{tabular}{lcc}
\hline Line & Wt Pct & At. pct \\
\hline O K & 26.1 & 58.6 \\
Ni K & 56.8 & 34.7 \\
Y L & 2.4 & 0.9 \\
Zr L & 14.7 & 5.8 \\
Total & 100 & 100 \\
\hline
\end{tabular}

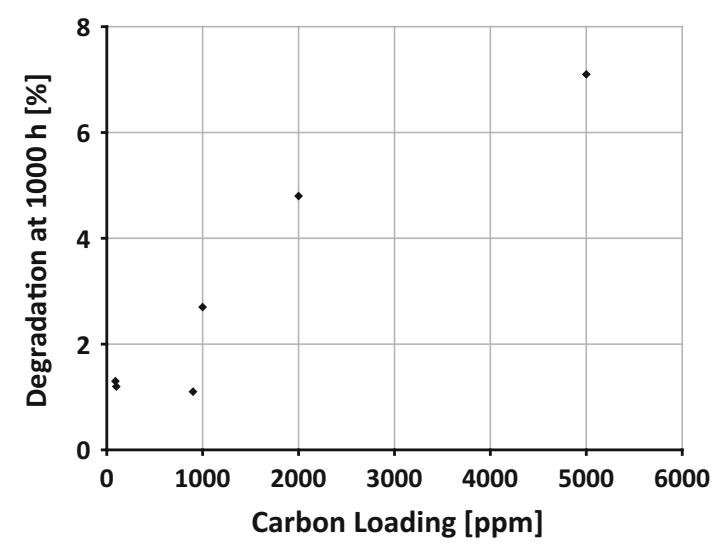

Fig. 12 - Performance degradation at $1000 \mathrm{~h}$ (in pct) as a function of total carbon loading. metal solution, changing the charge-transfer and ion transport characteristics of the anode active layer.

Given this evidence, formulation of an explicative model can begin. Broadly considered, an extrinsic contaminant material can induce degradation of the anode of a SOFC through three primary mechanistic classes. These mechanisms include ${ }^{[42]}$

- CLASS I-The physical blocking of fuel feed channels by filling the pores

- CLASS II-Surface adsorption which blocks the active TPB sites

- CLASS III-The formation of secondary nickel phases within the anode structure (A) and/or the formation of solid metal solutions (B)

Hackett ${ }^{[42]}$ has previously provided arguments that onephase decay processes are associated with Class I and Class IIIB mechanisms. The collected performance data are best modeled using the one-phase decay model, therefore implying that degradation is induced either through pore restrictions or via formation of new phases possessing altered properties relative to the base nickel. Solid carbon has the potential to block the fuel feed pores if formed via the Boudouard reaction (Eq. [2]) with the nickel acting as a catalyst, though carbon is not anticipated to form via methane cracking (Eq. [1]) due to the lack of methane in the syngas mixture. Unfortunately, bulk carbon formation and pore blockage are not detected in this system; therefore, it is necessary instead to consider the degradation of performance with respect to the total carbon activity of the source fuel. The EIS data also do not indicate any fuel diffusion resistance $(0.1$ to $1 \mathrm{~Hz})$, making this scenario less likely. A directly proportional relationship exists between total carbon exposure and the degradation rate above 1000 ppm carbon, as shown in Figure 12. Below a threshold of approximately 1000 ppm, the relationship to the performance degradation is either zero-order or indeterminate.

Since exposure to higher carbon activity fuel induces greater performance degradation and microstructural corruption, consideration must be given to Class III degradation processes. Although carbon does not produce a thermodynamically stable crystalline phase with nickel under the operating conditions examined here, carbon is soluble in nickel at 2.7 at. pct at $1600 \mathrm{~K}$

Table IV. Summary of Required Hydrocarbon Cleanup Levels Necessary to Maintain $0.6 \mathrm{~V}$ for 40,000 h of Cell Operation Based on a Normalized Starting Potential of $0.850 \mathrm{~V}$

\begin{tabular}{|c|c|c|c|c|c|}
\hline Test & Contaminant & Conc. (Ppm) & Initial Potential (V) & Percent Deg. & Final Potential (V) \\
\hline $\mathrm{BL}$ & none & $\mathrm{n} / \mathrm{a}$ & 0.850 & 24.0 & 0.646 \\
\hline 1 & benzene & 15 & 0.850 & 24.8 & 0.639 \\
\hline \multirow[t]{2}{*}{2} & benzene & 150 & 0.850 & 24.4 & 0.642 \\
\hline & benzene & $\mathrm{n} / \mathrm{a}$ & $\mathrm{n} / \mathrm{a}$ & $\mathrm{n} / \mathrm{a}$ & $\mathrm{n} / \mathrm{a}$ \\
\hline 3 & naphthalene & 100 & 0.850 & 26.0 & 0.629 \\
\hline \multirow[t]{2}{*}{4} & naphthalene & 500 & 0.850 & 30.4 & 0.591 \\
\hline & naphthalene & 400 & 0.850 & 29.4 & 0.600 \\
\hline 5 & ethylene & 50 & 0.850 & 24.8 & 0.639 \\
\hline \multirow[t]{2}{*}{6} & ethylene & 1000 & 0.850 & 30.0 & 0.595 \\
\hline & ethylene & 900 & 0.850 & 29.4 & 0.600 \\
\hline
\end{tabular}


$\left(1327{ }^{\circ} \mathrm{C}\right)$, and is soluble at approximately 1 at. pct near the cell operating temperature. ${ }^{[4]}$ It is plausible then that carbon is forming an amorphous solution with nickel, which is affecting physical properties of the nickel, even at low concentrations. For example, carbon dissolution could alter the overall nickel conductivity or catalytic properties, thereby impacting the $R_{\mathrm{P}}$. This postulation is supported by the EIS data. As this resistance continues to increase over time, cell performance will continue to degrade until the carbon solubility limit is reached. Once saturated, temporal degradation associated with carbon dissolution will cease and baseline cell degradation will dominate degradation in the cell's performance out to 40,000 hours. However, physical confirmation of this postulated mode remains lacking, as carbon was not significantly detectable by the applied analytical techniques, including HR-TEM.

Regardless of the assumed mechanism of attack, it is possible to use the collected degradation data to produce an empirical degradation rate on which a lifetime performance calculation may be based. The data collected over a relative short period of operation (500 hours) are here extrapolated to predict cell performance behavior to 40,000 hours. The data are modeled with a one-phase decay that most closely describes the performance degradation. This final model was determined using GraphPad statistical analysis software, which employs a well-developed outlier elimination method $^{[44]}$ to improve the data fitting process.

The one-phase decay trend indicates that the performance attack is only active within the first portion of the cell operation lifetime, followed by pure thermochemical (baseline) degradation. As previously noted, the baseline thermochemical degradation is assumed here to be linear over the entire duration. Therefore, the final fit to the assumed performance degradation appears as a dual-phase mixed degradation model featuring an initial period of one-phase decay to the point that the assumed linear baseline degradation rate ( $0.6 \mathrm{pct} / 1000$ hours) is reached. The degradation then continues at the baseline rate until 40,000 hours.

A model established as described above facilitates prediction of long-term operating potentials for the contaminant exposed samples. A normalized initial operating potential of $0.850 \mathrm{~V}$ (i.e., an overpotential of $0.115 \mathrm{~V}$, which is based on the result from the baseline test at $0.25 \mathrm{~A} \mathrm{~cm}^{-2}$ ) is assumed, and the measured degradation rates for each contaminant exposure are applied. A summary of final operating potentials for each contaminant exposure is provided in Table IV. Typically, a system manufacturer or designer will specify an acceptable lower threshold potential, below which the stack may not be operated for extended duration. Given an assumed minimum acceptable operating potential of $0.6 \mathrm{~V}$ (maximum overpotential of $0.365 \mathrm{~V}$ ), it is possible to predict maximum contaminant exposures that will result in the stack meeting lifetime performance requirements. As shown in Table IV, to maintain acceptable lifetime operation, naphthalene and ethylene must be cleaned to 400 and 900 ppm, respectively. The present data indicate that benzene may remain in the fuel stream at a concentration above $150 \mathrm{ppm}$, but an exact concentration threshold is indeterminable from these experiments.

If a minimum operating potential must be greater than $0.7 \mathrm{~V}$, the current model indicates that baseline degradation is too large for $40,000-h$ operation. The obvious method of improving the cell lifetime would be an improvement of the baseline cell degradation, which accounts for more than 80 pct of the realized total degradation at 40,000 hours. Simple catalytic cracking of fuel streams to possess HHC concentrations less than approximately $100 \mathrm{ppm}$ should also induce an improvement in cell lifetime performance.

\section{CONCLUSIONS}

In this work, simulated syngas containing $10+$ ppm levels of higher hydrocarbons represented by naphthalene, benzene, and ethylene are shown to more rapidly degrade the performance of anode-supported SOFC than exposure to simulated syngas free of higher hydrocarbons. The higher hydrocarbons appear to attack the nickel anode structure in a fuel cell in two ways. First, the carbon may facilitate indirect blockage of the fuel feed channels (by enhancing nickel mobility), resulting in fuel starvation or deactivation of the triple phase boundary sites within the anode. This scenario is less likely, given the lack of increase in resistance within the low frequency range associated with gas diffusion limitations from EIS data. Second, the carbon may diffuse into the nickel structure to a point where physical properties are altered and/or nickel metal dusting occurs, thereby diminishing the anode reaction activity, corrupting microstructure, and disrupting the conductive pathways. This is more likely and is supported by EIS data, showing an increase in resistance at the charge-transfer and ionic transport frequency range. A plausible lifetime performance model is constructed by combining contaminant-induced one-phase decay to a long-term linear decay. Using the model, and assuming a long-term operation target of 40,000 hours and a minimum final operating potential of $0.6 \mathrm{~V}$, naphthalene and ethylene must be reduced in the syngas stream to $400 \mathrm{ppm}$ and $900 \mathrm{ppm}$, respectively. An exact determination could not be made for benzene, but a current threshold of $150 \mathrm{ppm}$ is recommended.

\section{ACKNOWLEDGMENTS}

We would like to acknowledge James Poston, Jr. for the XPS analysis that he conducted on the samples. We would also like to thank Randall Gemmen for beneficial discussions and to acknowledge the NETLRegional University Alliance and West Virginia University. Part of this report was prepared as an account of work sponsored by an agency of the United States Government. Neither the United States Government nor any agency thereof, nor any of their employees, makes any warranty, express or implied, or assumes any legal liability or responsibility for the 
accuracy, completeness, or usefulness of any information, apparatus, product, or process disclosed, or represents that its use would not infringe privately owned rights. Reference herein to any specific commercial product, process, or service by trade name, trademark, manufacturer, or otherwise does not necessarily constitute or imply its endorsement, recommendation, or favoring by the United States Government or any agency thereof. The views and opinions of authors expressed herein do not necessarily state or reflect those of the United States Government or any agency thereof.

\section{NOMENCLATURE}

$\begin{array}{ll}\text { c-YSZ } & \text { Cubic yttria stabilized zirconia } \\ \text { DOE } & \text { Department of Energy } \\ \text { EDS } & \text { Energy dispersive X-ray spectroscopy } \\ \text { EIS } & \text { Electrochemical impedance spectroscopy } \\ E_{\mathrm{N}} & \text { Nernst potential } \\ \text { FC } & \text { Fuel cell } \\ \text { HC } & \text { Hydrocarbon } \\ \text { HHC } & \text { Higher hydrocarbon } \\ \text { HR-TEM } & \text { High resolution transmission electron } \\ & \text { microscopy } \\ \text { IGFC } & \text { Integrated gasification/fuel cell } \\ \text { LSM } & \text { Lanthanum-strontium-manganate } \\ \text { MSRI } & \text { Materials and Systems Research, } \\ & \text { Incorporated } \\ \text { NETL } & \text { National Energy Technology Laboratory } \\ \text { Ni/YSZ } & \text { Nickel/yttria stabilized zirconia } \\ \text { OCV } & \text { Open circuit voltage } \\ R^{2} & \text { Coefficient of determination } \\ R_{\mathrm{P}} & \text { Polarization resistance } \\ \text { SEM } & \text { Scanning electron microscope } \\ \text { SEM/EDS } & \text { Scanning electron microscopy/energy } \\ & \text { dispersive spectroscopy } \\ \text { SOFC } & \text { Solid oxide fuel cell } \\ \text { TEM } & \text { Transmission electron microscopy } \\ \text { TPB } & \text { Triple-phase boundary } \\ \text { t-YSZ } & \text { Tetragonal yttria stabilized zirconia } \\ \text { XPS } & \text { X-ray photoelectron spectroscopy } \\ \text { YSZ } & \text { Yttria stabilized zirconia } \\ & \end{array}$

\section{REFERENCES}

1. C. Higman and M. van der Burgt: Gasification, Elsevier, Amsterdam, 2003.

2. S.C. Singhal: Solid State Ionics, 2000, vol. 135, pp. 305-13.

3. C.W. Sun and U. Stimming: J. Power Sources, 2007, vol. 171, pp. 247-60.

4. S.M. Haile: Acta Mater., 2003, vol. 51, pp. 5981-6000

5. T. Horita, H. Kishimoto, K. Yamaji, Y.P. Xiong, N. Sakai, M.E. Brito, and H. Yokokawa: Solid State Ionics, 2006, vol. 177, pp. 1941-48.

6. P. Kuchonthara, S. Bhattacharya, and A. Tsutsumi: Fuel, 2005, vol. 84, pp. 1019-21.

7. T. Kivisaari, P. Bjornbom, C. Sylwan, B. Jacquinot, D. Jansen, and A. de Groot: Chem. Eng. J., 2004, vol. 100, pp. 167-80.

8. A. Milbrandt: A Geographic Perspective on the Current Biomass Resource Availability in the United States, Technical Report, NREL, 2005.
9. J. Mermelstein, M. Millan, and N.P. Brandon: Chem. Eng. Sci., 2009, vol. 64, pp. 492-500.

10. J. Ratafia-Brown, L. Manfredo, J. Hoffmann, and M. Ramezan: Major Environmental Aspects of Gasification-Based Power Generation Technologies, Final Report, Technical Report, U.S. Department of Energy, 2002.

11. Fuel Cells Bulletin, 2003, p. 2.

12. P. Lohsoontorn, D.J.L. Brett, and N.P. Brandon: J. Power Sources, 2008, vol. 175, pp. 60-67.

13. J. Bao, G.N. Krishnan, P. Jayaweera, K.H. Lau, and A. Sanjurjo: J. Power Sources, 2009, vol. 193, pp. 617-24

14. J. Bao, G.N. Krishnan, P. Jayaweera, J. Perez-Mariano, and A. Sanjurjo: J. Power Sources, 2009, vol. 193, pp. 607-16.

15. J.E. Bao, G.N. Krishnan, P. Jayaweera, and A. Sanjurjo: J. Power Sources, 2010, vol. 195, pp. 1316-24.

16. J. Trembly, J. Albritton, and R. Gupta: in Coal Based Fuel Cell Technology, Morgantown, WV, 2007.

17. J.P. Trembly, R.S. Gemmen, and D.J. Bayless: J. Power Sources, 2007, vol. 171, pp. 818-25.

18. J.P. Trembly, R.S. Gemmen, and D.J. Bayless: J. Power Sources, 2007, vol. 169 , pp. 347-54

19. J.P. Trembly, R.S. Gemmen, and D.J. Bayless: in 5th Fuel Cell Science, Engineering, and Technology Conference, ASME, New York, NY, 2007.

20. C.C. Xu, M.Y. Gong, J.W. Zondlo, X.B. Liu, and H.O. Finklea: J. Power Sources, 2010, vol. 195, pp. 2149-58.

21. C.C. Xu, J.W. Zondlo, H.O. Finklea, O. Demircan, M.Y. Gong, and X.B. Liu: J. Power Sources, 2009, vol. 193, pp. 739-46.

22. G.N. Krishnan: Effect of Coal Contaminants on Solid Oxide Fuel System Performance and Service Life, Technical Report, SRI International, 2006.

23. E.R. Ray and N.J. Maskalick: in Joint Contractors Meeting: FE/EE Advanced Turbine Systems Conference, FE Fuel Cells, and CoalFired Heat Engines Conference, Morgantown, WV, 1993, pp. 1-10.

24. J.P. Trembly, R.S. Gemmen, and D.J. Bayless: J. Power Sources, 2007, vol. 163, pp. 986-96.

25. K. Gerdes, A. Martinez, R. Gemmen, and J. Poston: J. Power Sources, 2010, vol. 195, pp. 5206-12.

26. L. Devi, K.J. Ptasinski, and F.J.J.G. Janssen: Biomass Bioenergy, 2003, vol. 24, pp. 125-40.

27. D. Singh, E. Hernandez-Pacheco, P.N. Hutton, N. Patel, and M.D. Mann: J. Power Sources, 2005, vol. 142, pp. 194-99.

28. H.S. Bengaard, J.K. Nørskov, J. Sehested, B.S. Clausen, L.P. Nielsen, A.M. Molenbroek, and J.R. Rostrup-Nielsen: J. Catal., 2002, vol. 209, pp. 365-84

29. T.A. Milne, R.J. Evans, and N. Abatzaglou: in N.R.E. Laboratory, I. Kemestrie, eds., U.S. Department of Energy, Golden, CO, 1998.

30. D. Singh, E. Hernández-Pacheco, P.N. Hutton, N. Patel, and M.D. Mann: J. Power Sources, 2005, vol. 142, pp. 194-99.

31. R. Coll, J. Salvadó, X. Farriol, and D. Montané: Fuel Process. Technol., 2001, vol. 74, pp. 19-31.

32. C. Endler, A. Leonide, A. Weber, F. Tietz, and E. Ivers-Tiffée: J. Electrochem. Soc., 2010, vol. 157, pp. B292-98.

33. Y. Chen, S. Chen, G. Hackett, H. Finklea, X. Song, and K. Gerdes: Solid State Ionics, 2011, vols. 204-205, pp. 87-90.

34. S. Chen, Y. Chen, H. Finklea, X. Song, G. Hackett, and K. Gerdes: Solid State Ionics, 2012, vol. 206, pp. 104-11.

35. J.-H. Koh, Y.-S. Yoo, J.-W. Park, and H.C. Lim: Solid State Ionics, 2002, vol. 149, pp. 157-66.

36. C.M. Chun, J.D. Mumford, and T.A. Ramanarayanan: J. Electrochem. Soc., 2000, vol. 147, pp. 3680-86.

37. C.M. Chun, G. Bhargava, and T.A. Ramanarayanan: J. Electrochem. Soc., 2007, vol. 154, pp. C231-40.

38. J.Q. Zhang and D.J. Young: Corros. Sci., 2007, vol. 49, pp. 14961512.

39. H. Liu and W. Chen: J. Electrochem. Soc., 2007, vol. 154, p. C522.

40. R.T. Jones and K.L. Baumert: in Corrosion 2001, N. International, ed., NACE International, Houston, TX, 2001.

41. H. He and J.M. Hill: Appl. Catal. A, 2007, vol. 317, pp. 284-92.

42. G.A. Hackett: Ph.D. Thesis, West Virginia University, 2009.

43. L. Alvarez, T. Guillard, J.L. Sauvajol, G. Flamant, and D. Laplaze: Chem. Phys. Lett., 2001, vol. 342, pp. 7-14.

44. H.J. Motulsky and R.E. Brown: BMC Bioinformatics, 2006, vol. 7, p. 123. 